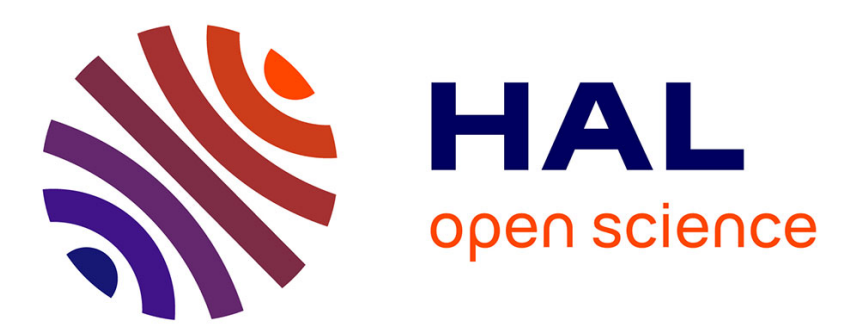

\title{
The effect of selective oxidation of chromium on the creep strength of alloy 617
}

\author{
P. Ennis, W. Quadakkers, H. Schuster
}

\section{To cite this version:}

P. Ennis, W. Quadakkers, H. Schuster. The effect of selective oxidation of chromium on the creep strength of alloy 617. Journal de Physique IV Proceedings, 1993, 03 (C9), pp.C9-979-C9-986. 10.1051/jp4:19939101 . jpa-00252343

\section{HAL Id: jpa-00252343 https://hal.science/jpa-00252343}

Submitted on 1 Jan 1993

HAL is a multi-disciplinary open access archive for the deposit and dissemination of scientific research documents, whether they are published or not. The documents may come from teaching and research institutions in France or abroad, or from public or private research centers.
L'archive ouverte pluridisciplinaire HAL, est destinée au dépôt et à la diffusion de documents scientifiques de niveau recherche, publiés ou non, émanant des établissements d'enseignement et de recherche français ou étrangers, des laboratoires publics ou privés. 


\title{
The effect of selective oxidation of chromium on the creep strength of alloy 617
}

\author{
P.J. Ennis, W.J. Quadakkers and H. Schuster
}

Research Centre (KFA) Juelich, Institute for Reactor Materials, Postfach 1913, 5170 Juelich 1, Germany

\begin{abstract}
In order to investigate the effect on creep strength of the selective oxidation of chromium which causes the formation of a carbide-free subsurface zone, specimens of Ni22Cr12Co9MolAl (Alloy 617) were subjected to heat treatments to simulate a long-term service exposure of a thin-walled heat exchanger tube operating at high temperatures. In creep tests carried out at $900^{\circ} \mathrm{C}$, specimens with extensive chromium-depleted and carbide-free subsurface zones exhibited higher creep strength than specimens thermally aged for the same durations, but having no carbide-free zone. The carbon released by dissolution of the carbides in the chromium-depleted zone migrated to the centre of the specimen, producing enhanced carbide precipitation. This led to an increase in the creep strength of the specimen core which offset the loss in creep strength of the subsurface zone.
\end{abstract}

\section{Introduction.}

Several literature reviews have been published on the interaction between corrosion processes and chemical deformation processes, for example, Cook and Skelton [1], Guttmann and Marriott [2], Guttmann and Schuetze [3].

The principal problem in the investigation and evaluation of corrosion-creep interactions is that creep is a volume effect, whereas corrosion is a surface effect. The magnitude of the measured interaction will, therefore, depend on the surface area to volume ratio, more precisely on the thickness of the corrosion-affected zone in relation to the total specimen crosssection. The experimental conditions, especially specimen size and corrosive atmosphere, have to be chosen to reflect the specific application for which the corrosion-creep interaction is to be investigated.

Most commercial high temperature alloys rely for their oxidation resistance on the selective oxidation of chromium to form a protective chromia scale. The associated loss of chromium from the matrix reduces the solid-solution strengthening and also leads to dissolution of chromium carbides in the chromium-depleted zone as the chromium activity decreases, as shown by Quadakkers and Schuster [4]. Von der Gracht $e t$ al. [5] demonstrated the importance of carbides, especially those at the grain boundaries, for long-term creep-rupture strength of the alloy Ni-23Cr-12Co-9Mo-1 Al-0.08C (INCONEL alloy 617).

The specific aim of this research was to investigate whether the chromium-depleted (and therefore carbide-free) zone resulting from chromia scale formation on a thin-walled, heat exchanger tube (20 mm diameter, $2 \mathrm{~mm}$ wall thickness) of alloy 617 reduces the creep strength of the tube wall during long term service at $900^{\circ} \mathrm{C}$, as expected from decarburization experiments [5]. 


\section{Experimental details.}

The details of the heat tested are given in table I. The material was supplied in the solution treated condition $\left(1 \mathrm{~h}\right.$ at $1175{ }^{\circ} \mathrm{C}$, water quenched). Three types of test specimen were produced as follows:

- the as-received plate was machined to $2 \mathrm{~mm}$ thick, flat tensile specimens (referred to as "solution treated");

- specimen blanks were cut from the as-received plate and aged at $1000^{\circ} \mathrm{C}$ in air for 1000 , 3000 and $6000 \mathrm{~h}$. The oxidation-affected surface zone was removed during machining to $2 \mathrm{~mm}$ thick, flat tensile specimens (referred to as "aged");

- $2 \mathrm{~mm}$ thick, flat test pieces were machined from as-received plate and oxidized at $1000^{\circ} \mathrm{C}$ in air for 1000,3000 and $6000 \mathrm{~h}$ with no further treatment of test pieces before creep testing, so that the oxidation-affected zone was preserved (referred to as "oxidized").

Table I. - Details of the test material.

\begin{tabular}{|c|c|c|c|c|c|}
\hline \multirow{4}{*}{\multicolumn{2}{|c|}{$\begin{array}{l}\text { Alloy } \\
\text { Manufacturer } \\
\text { Heat no } \\
\text { Form } \\
\text { Heat treatment }\end{array}$}} & \multicolumn{4}{|c|}{$\begin{array}{l}\text { INCONEL alloy } 617 \\
\text { Inco Alloys International } \\
\text { XX12A9UK }\end{array}$} \\
\hline & & \multicolumn{4}{|c|}{$7.6 \mathrm{~mm}$ thick hot - rolled plate } \\
\hline & & \multicolumn{4}{|c|}{ solution annealed } \\
\hline & & \multicolumn{4}{|c|}{$\left(1 \mathrm{~h}\right.$ at $\left.1175^{\circ} \mathrm{C} \mathrm{WQ}\right)$} \\
\hline \multicolumn{6}{|c|}{ Chemical composition (manufacturer's data), wt\%: } \\
\hline $\mathrm{C}\left({ }^{*}\right)$ & 0.07 & $\mathrm{Ni}$ & 54.92 & $\mathrm{Fe}$ & 0.97 \\
\hline $\mathrm{Mn}$ & 0.03 & $\mathrm{Cr}$ & 21.97 & $\mathrm{~S}$ & 0.002 \\
\hline $\mathrm{Si}$ & 0.16 & Co & 12.12 & & \\
\hline $\mathrm{Al}$ & 1.12 & Mo & 8.65 & & \\
\hline
\end{tabular}

$\left(^{*}\right)$ KFA carbon analysis 0.076 .

Figure 1 illustrates the specimen preparation procedures and the geometry of the specimens used for the creep tests. The effect of thermal ageing and the effect of a chromiumdepleted and thus carbide-free zone could be distinguished. The specimen thickness was chosen to correspond to the wall thickness of the heat exchanger tube under consideration. The time and duration of the oxidation exposure were selected so that the chromium-depleted zone would form $50 \%$ of the total cross-section of the specimens after the longest exposure time, representing the extent of the depleted zone for a tube after about $100000 \mathrm{~h}$ at $900^{\circ} \mathrm{C}$ in an oxidizing environment. The specimens were tested in a multi-specimen creep machine, 
the creep strain being measured at test interruptions. Tests were carried out at $900{ }^{\circ} \mathrm{C}$ under a nominal stress of $32 \mathrm{MPa}$ in air. Based on previous creep tests, the expected time to rupture for the solution treated material was about $15000 \mathrm{~h}$. Pretreatments of aged and oxidized specimens at $1000^{\circ} \mathrm{C}$ produced corrosion effects equivalent to $100000 \mathrm{~h}$ exposure at $900{ }^{\circ} \mathrm{C}$ so that corrosion occurring during the creep testing could to a first approximation be ignored.

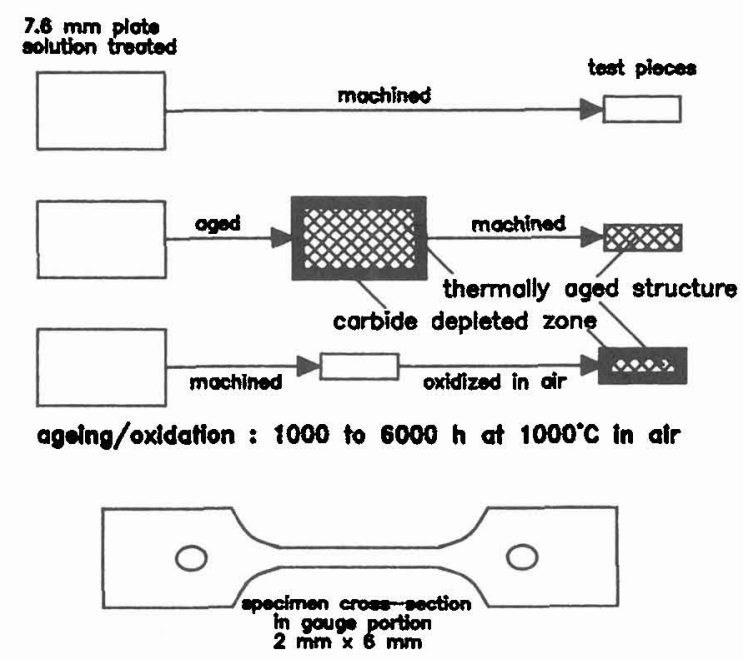

Fig. 1. - Creep test piece preparation and specimen geometry.

\section{Results.}

3.1 CHROMIUM-DEPLETION EFFECTS. - The microstructure of the near-surface region of a specimen after an oxidation exposure of $6000 \mathrm{~h}$ at $1000^{\circ} \mathrm{C}$ is shown in figure 2, which shows:

- a zone in which internal oxidation of aluminium had occurred, with formation of $\mathrm{Al}_{2} \mathrm{O}_{3}$;

- the formation of pores presumably due to the Kirkendall effect;

- a carbide-free zone resulting from chromium depletion.

The oxide scale thickness, the depth of the internally oxidized zone, the extent of the Kirkendall porosity zone and the depth of the carbide-free zone are shown in figure 3 as functions of the exposure time at $1000^{\circ} \mathrm{C}$.

3.2 CREEP TEST RESULTS. - The creep curves determined for solution treated specimens, for thermally aged specimens (no initial carbide-free zone) and for oxidized specimens (with initial carbide-free zone) are shown in figure 4 . The highest creep strength was exhibited by the solution treated specimen in agreement with [5]. Thermally aged specimens exhibited low creep strength and in fact the specimen aged for $6000 \mathrm{~h}$ at $1000^{\circ} \mathrm{C}$ prior to creep testing at $900^{\circ} \mathrm{C}$ ruptured at around $6000 \mathrm{~h}$. Surprisingly, the specimens with extensive carbide-free zones exhibited a secondary creep rate similar to that of the solution treated 


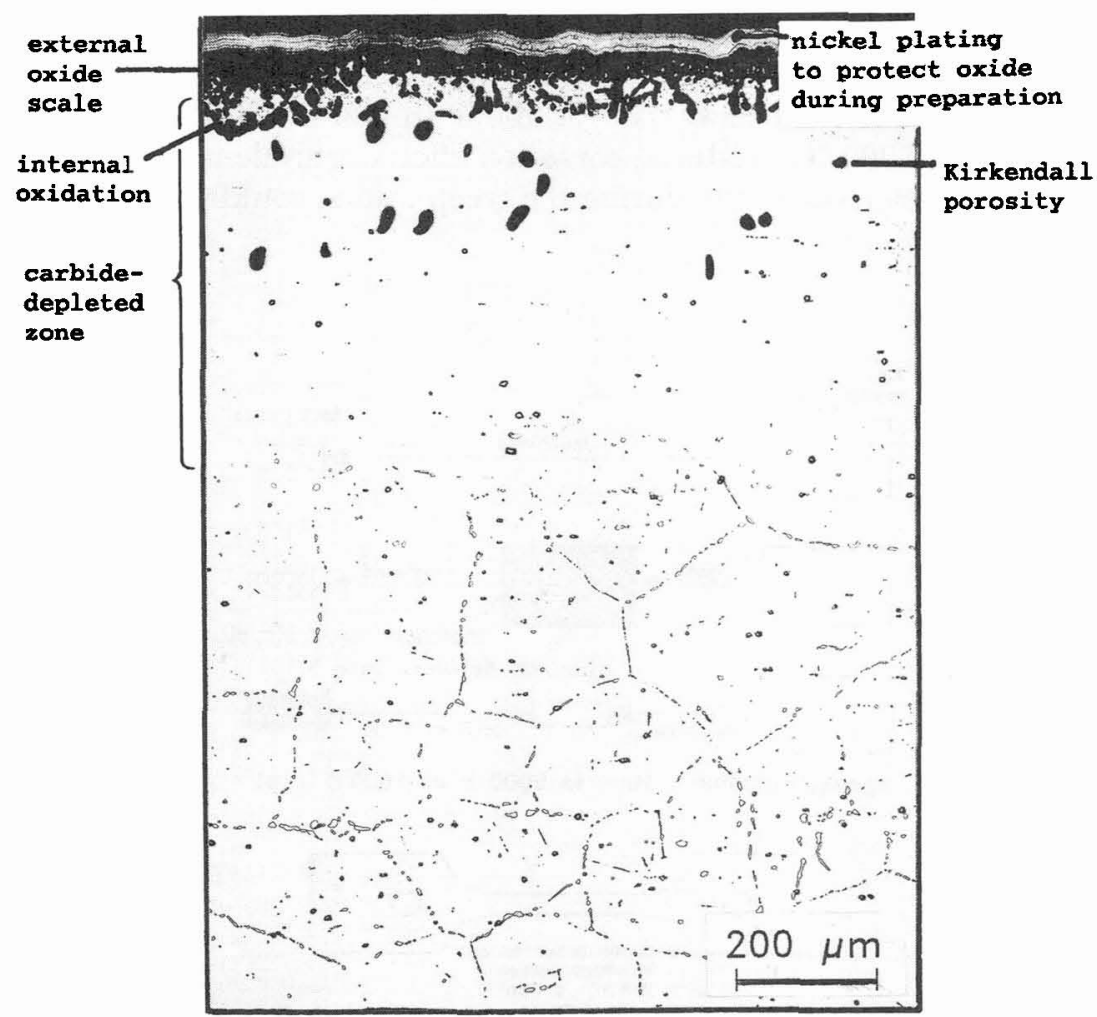

Fig. 2. - Microstructure of alloy 617 after $6000 \mathrm{~h}$ oxidation in air at $1000^{\circ} \mathrm{C}$, showing the chromiumdepleted and carbide-free zone.

specimen although there was a more pronounced primary creep region. These specimens were examined metallographically to establish the reason for the unexpectedly high creep resistance.

3.3 METALLOGRAPHY OF CREEP SPECIMENS. - During the creep tests further chromiumdepletion occurred as the surface oxide was formed. Figure 5 shows the microstructure of two specimens without an initial carbide-free zone (one solution treated and one thermally aged) after creep testing. Because the creep tests were carried out at a lower temperature than the oxidation exposure prior to testing, the carbide-free zone produced by oxidation of chromium during the creep test was rather narrow, even after $15000 \mathrm{~h}$. From the figure, the depth of this zone was estimated at $0.1 \mathrm{~mm}$; this can be compared with a carbide-free zone of about $0.5 \mathrm{~mm}$ produced by prior oxidation at $1000^{\circ} \mathrm{C}$ for $6000 \mathrm{~h}$. The additional chromium depletion during the creep test can, therefore, to a first approximation be neglected. The thermally aged creep specimen exhibited evidence of nitridation, aluminium/titanium nitride needles having formed around surface cracks. The presence of surface cracks seems to be a prerequisite for nitridation effects, as no nitrides were observed in the solution treated specimen which did not exhibit surface cracks (see Fig. 5).

Figure 6 compares the microstructures of the thermally aged $\left(6000 \mathrm{~h}\right.$ at $\left.1000^{\circ} \mathrm{C}\right)$ specimen and the oxidized specimen $\left(6000 \mathrm{~h}\right.$ at $1000^{\circ} \mathrm{C}, 0.5 \mathrm{~mm}$ deep carbide-free zone) after creep 


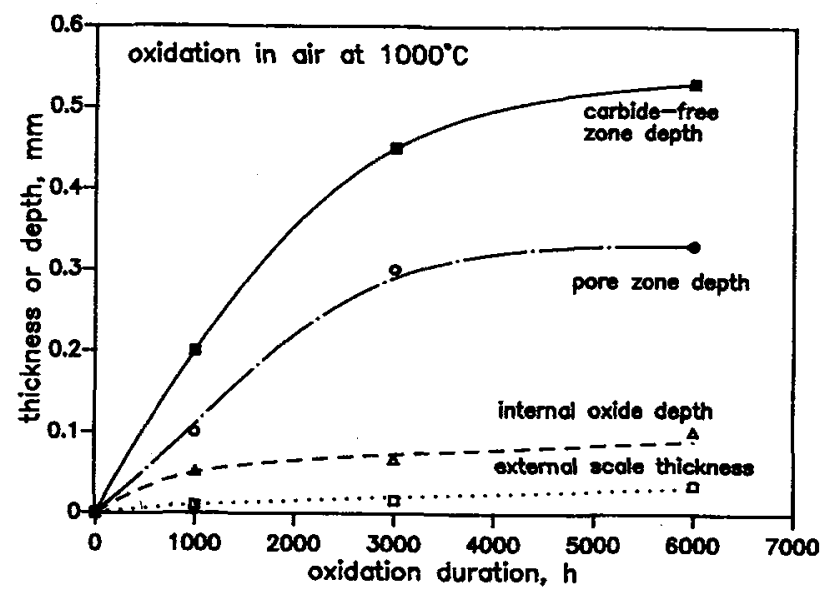

Fig. 3. - External scale thickness, depth of internal oxidation, depth of the zone containing Kirkendall pores and depth of the carbide-free (chromium-depleted) zone, plotted as functions of oxidation time at $1000{ }^{\circ} \mathrm{C}$.
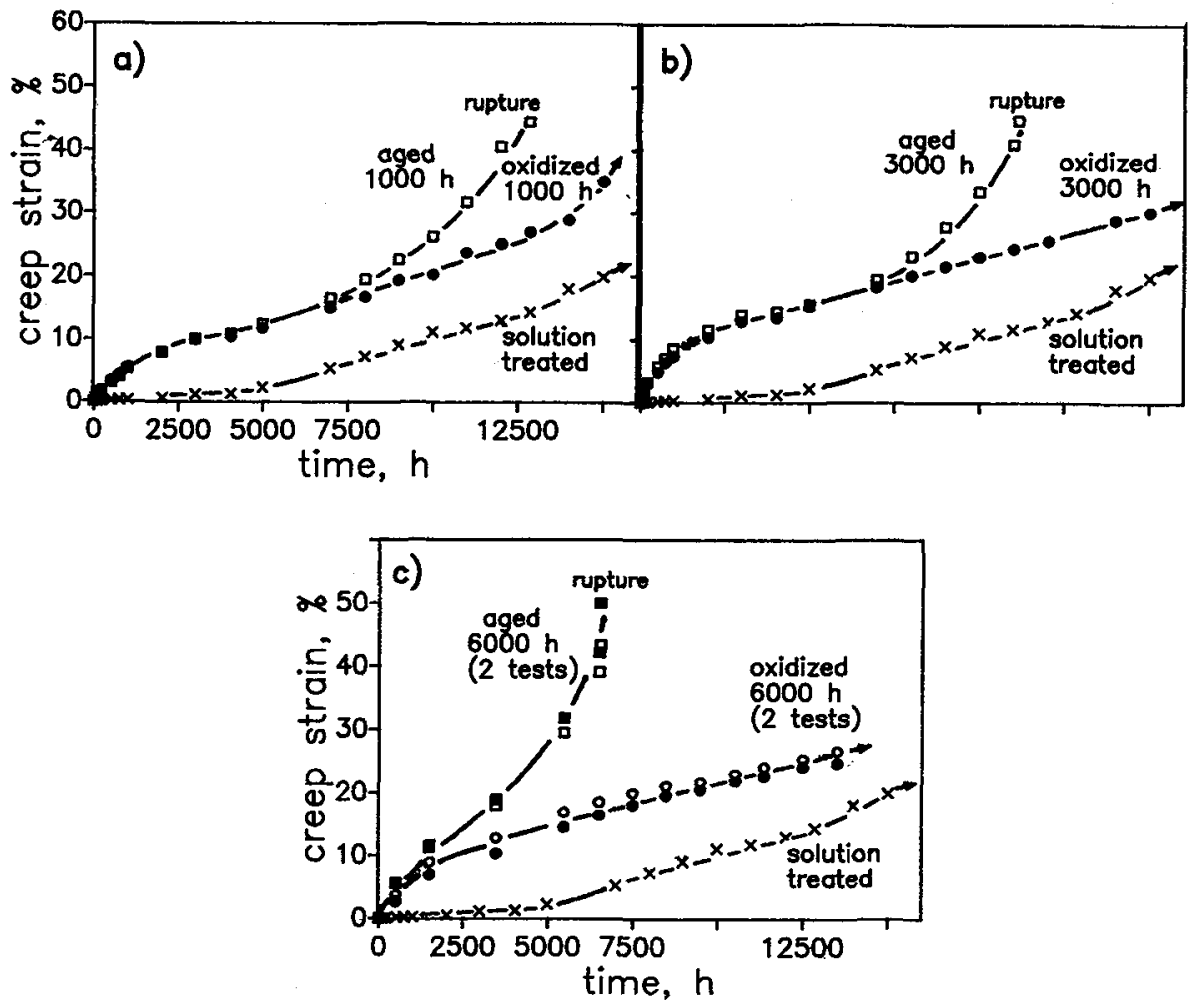

Fig. 4. - Creep curves for solution treated, for aged and for oxidized alloy 617 at $32 \mathrm{MPa}, 900{ }^{\circ} \mathrm{C}$ : a) $1000 \mathrm{~h}$; b) $3000 \mathrm{~h}$; c) $6000 \mathrm{~h}$. 


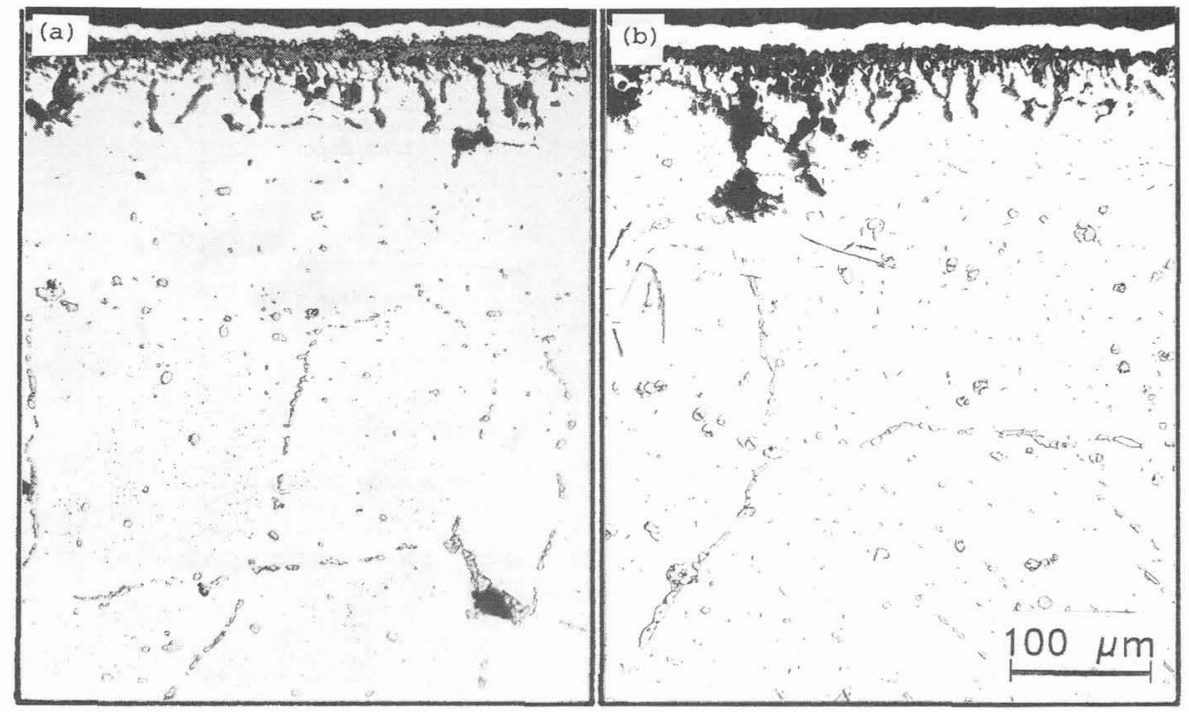

Fig. 5. - Microstructure of tested creep specimens: a) solution treated specimen, tested for $15000 \mathrm{~h}$, $32 \mathrm{MPa}, 900^{\circ} \mathrm{C}$, creep strain $20 \%$; b) specimen aged for $6000 \mathrm{~h}$ at $1000^{\circ} \mathrm{C}$ prior to creep testing at $32 \mathrm{MPa}, 900^{\circ} \mathrm{C}$, rupture at $6877 \mathrm{~h}, 65 \%$. Note the coarser carbide precipitation in the aged specimen.

testing. Higher magnification photomicrographs are shown in figure 7. It can be seen that the core region of the oxidized specimen contains more extensive carbide precipitation than the core region of the thermally aged specimen. This was confirmed by carbon analysis of the core regions of creep specimens, carried out after grinding $0.5 \mathrm{~mm}$ from each side of the specimens. The results of the combustion analysis for carbon are given in table II.

Table II. - Carbon analysis of creep tested specimens.

\begin{tabular}{|c|c|c|}
\hline $\begin{array}{c}\text { specimen pre-test } \\
\text { treatment }\end{array}$ & $\begin{array}{c}\text { test time, } \mathrm{h} \\
\text { and strain, \% }\end{array}$ & $\begin{array}{c}\mathrm{C} \text { content } \\
\text { in central l } \mathrm{l} \text { mm zone }\end{array}$ \\
\hline sol.ann. & $15000 / 20$ & 0.076 \\
aged $1000 \mathrm{~h} / 1000^{\circ} \mathrm{C}$ & $15000 / 45$ & 0.076 \\
oxid. $3000 \mathrm{~h} / 1000^{\circ} \mathrm{C}$ & $12850 / 30$ & 0.088 \\
oxid. $6000 \mathrm{~h} / 1000^{\circ} \mathrm{C}$ & $13490 / 25$ & 0.107 \\
\hline
\end{tabular}

$\left({ }^{*}\right)$ carbon determined by combustion analysis.

\section{Discussion.}

Figure 4 shows that the heat treated and the oxidized specimens exhibited a more extensive primary creep region than the solution treated specimen. The shape of the creep curve for 


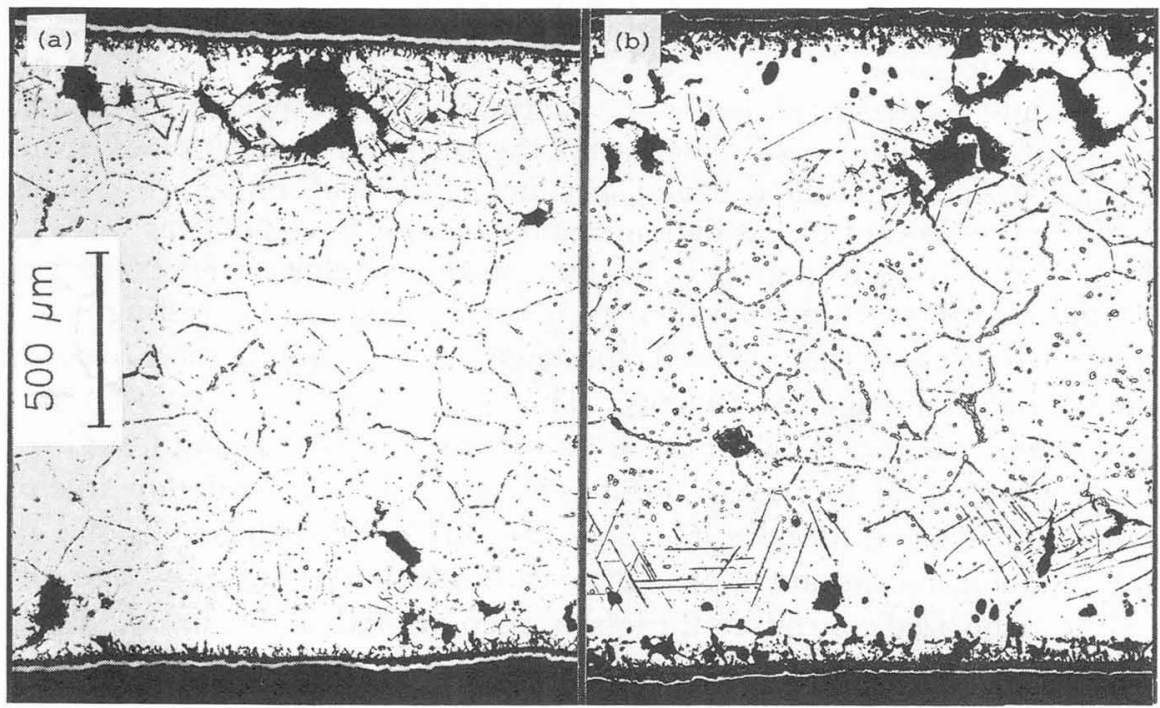

Fig. 6. - Comparison of the microstructures of: a) aged and b) oxidized creep tested specimens; ageing and oxidation for $6000 \mathrm{~h}$ at $1000^{\circ} \mathrm{C}$ prior to creep testing at $32 \mathrm{MPa}, 900^{\circ} \mathrm{C}$.

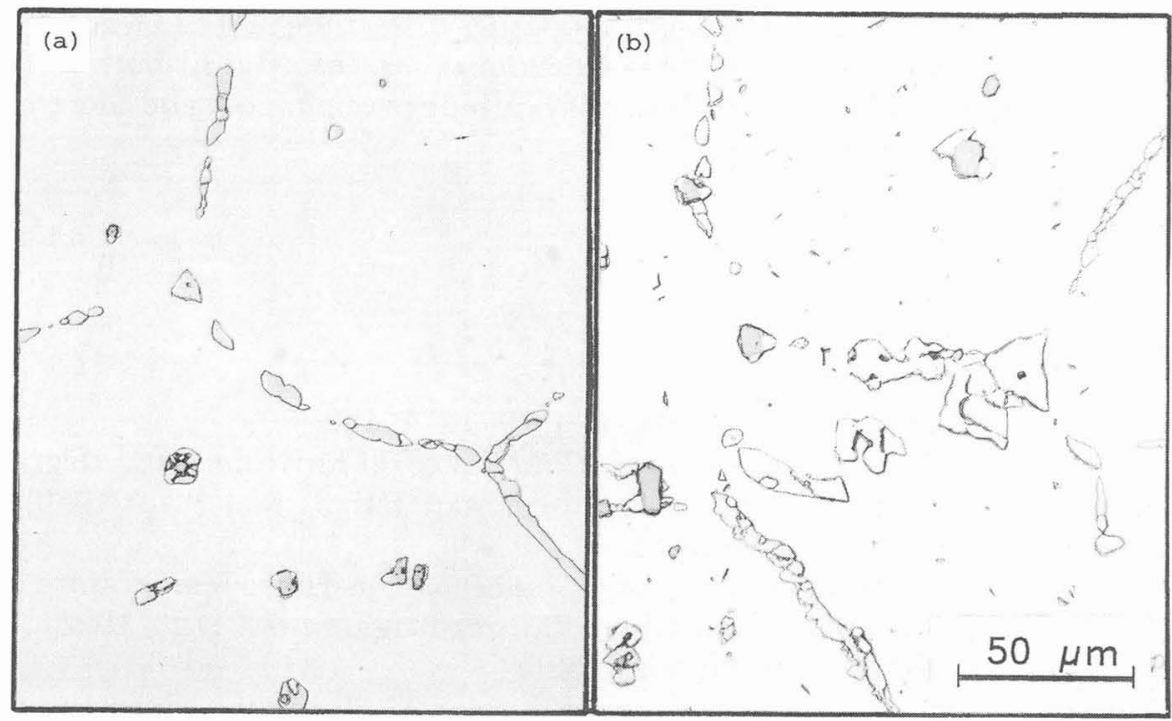

Fig. 7. - High magnification photomicrographs of the central region of: a) aged and b) oxidized creep specimens of figure 6 , showing enhanced carbide precipitation in the oxidized specimen core.

the solution treated condition indicated a low creep rate for the first $5000 \mathrm{~h}$ and then a higher constant creep rate region. Plate materials are often subjected to a flattening treatment after solution annealing introducing a small amount of cold work which can have a short-term strengthening effect. The initial creep strengthening in the solution treated condition can 
also arise from the precipitation of fine carbides during the early stages of testing as reported by Schneider et al. [6].

In the aged and oxidized specimens the thermal exposure prior to testing has caused coarsening of the precipitates before the start of the creep test and a more extensive primary creep region is observed. All the oxidized specimens exhibited similar creep behaviour and the effect of the duration of the oxidation treatment prior to testing was small. The creep curves of the thermally aged specimens, in contrast, showed that onset of tertiary creep and rupture occurred at shorter times for increasing ageing time prior to testing.

The creep strength of the oxidized specimens was clearly higher than that of the corresponding thermally aged specimens. This unexpected result shows that there is a significant difference between loss of carbides through decarburization (selective oxidation of carbon) discussed in [5] and loss of carbides through selective oxidation of chromium, in which the carbon released into the matrix as the chromium carbides dissolve migrates to the central region of the specimen, producing carburization of the core. The higher creep strength of the carburized core offsets the loss in creep strength of the carbide-depleted zone.

\section{Conclusion.}

For the specific application under consideration (a thin-walled heat exchanger tube of alloy 617 operating at around $900{ }^{\circ} \mathrm{C}$ in an oxidizing atmosphere) the selective oxidation of chromium produces a chromium-depleted, carbide-free subsurface zone but this does not lead to a deterioration in the creep strength properties of the tube wall as a whole. The lower strength of the chromium-depleted, carbide-free zone is offset by a redistribution of carbon in the matrix to produce enhanced grain-boundary carbide precipitation, and therefore higher creep strength, in the core of the specimen.

\section{References}

[1] COOK R.H., SKELTON R.P., Int. Met. Rev. 19 (1974) 199.

[2] Guttmann V., Marriott J.B., Proc. Conference on Environmental Degradation of High Temperature Materials, Vol. 2 (Isle of Man, UK, 31 Mar-3 Apr 1980) (Institute of Metals, London, 1980) paper 13.

[3] Guttmann V., Schuetze M., Proc. Conference on High Temperature Alloys for Gas Turbines and Other Applications (Liège, Belgium, 6-8 Oct. 1986) (D. Reidel Publishing, EUR 10567, 1986) p. 293-326.

[4] Quadakkers W., Schuster H., Proc. Eurocorr 87 (Karlsruhe, Germany, 6-10 April 1987) p. 99-104.

[5] VON DER GRACHT R., ENNIS P.J., CZYRSKA-FILEMONOWICZ A., NiCKEL H., SCHUSTER H., Proc. Int Conference on Creep (Tokio, Japan, 14-18 April 1986) p. 123-128.

[6] Schneider K., Hartnagel W., SChepP P., IlSChNer B., Nucl. Technol. 66 (1984) 289-295. 